Benha Veterinary Medical Journal 41 (2021) 19-23

\begin{tabular}{|c|c|c|}
\hline & Benha Veterinary Medical Journal & 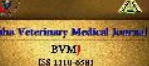 \\
\hline $\begin{array}{l}\text { Official Journal Issued by } \\
\text { Faculty of } \\
\text { Veterinary Medicine }\end{array}$ & Journal homepage: https://bvmj.journals.ekb.eg/ & $\begin{array}{c}=7 \\
\text { Since } 1990\end{array}$ \\
\hline
\end{tabular}

Original Paper

\title{
Prevalence and risk factors of clinical mastitis in Holstein cows under subtropical Egyptian conditions
}

Dina N. Faris ${ }^{1}$, Khairy M. El-Bayoumi², Mahmoud S. El-Tarabany ${ }^{2}$, Amira M. Abd-El Hamed ${ }^{1}$, Eman R. Kamel $^{1}$

${ }^{1}$ Department of Animal Wealth Development, Faculty of Veterinary Medicine, Benha University, P.O. Box 13736, Egypt

${ }^{2}$ Department of Animal Wealth Development, Faculty of Veterinary Medicine, Zagazig University, P.O. Box 44511, Egypt

\section{ARTICLE INFO}

Keywords

Clinical mastitis

Holsteins

Logistic regression

Risk factors.

Received 31/07/2021

Accepted 4/08/2021

Available On-Line

$01 / 10 / 2021$

\begin{abstract}
The current study was built on 1015 dairy records of Holstein Friesian cows, aimed to determine the prevalence and potential risk factors of clinical mastitis (CM). Logistic regression models were conducted to determine the risk factors associated with the onset of $\mathrm{CM}$. The average age at $1^{\text {st }}$ calving was 1.98 years in mastitic cows, and 2.01 years in healthy ones. Daily milk yield (DMY) was shown to be somewhat lower in mastitic cows than in healthy (31.9 and $32.3 \mathrm{~kg}$, respectively). Older dairy cows $>5$ years had a higher incidence of mastitis $(53.56 \%)$. The prevalence of $\mathrm{CM}$ was higher in multiparous cows, either $2^{\text {nd }}$ parity $(48.24 \%)$ or $\geq 3^{\text {rd }}$ parity $(47.23 \%)$. Regarding the calving season, cows that calved in winter showed a lower percentage of CM (38.36\%). Pregnant cows were found to have a greater incidence of CM than non-pregnant cows (59.35\% and $32.89 \%$, respectively). Concerning the history of the previous mastitis, cows that were infected previously showed a higher prevalence of CM $(51.66 \%)$. The greatest percentage of $\mathrm{CM}$ was observed in cows in the early and mid-stages of lactation (44.59\% and $52.69 \%$, respectively). The final multivariate logistic regression model revealed that age at $1^{\text {st }}$ calving had a significant positive correlation with the incidence of $\mathrm{CM}(\beta=1.19, P$-value $=0.003)$. Older cows $>5$ years (odds ratio $(\mathrm{OR})=1.79)$, cows calved during the summer season $(\mathrm{OR}=1.84)$, Pregnant cows $(\mathrm{OR}=7.27)$, cows with a history of previous mastitis $(\mathrm{OR}=1.81)$, and lactating cows at early lactation stage (1-90 days) were significant risk factors associated with an increased incidence of CM.
\end{abstract}

\section{INTRODUCTION}

Mastitis is considered an endemic disorder in the dairy sector all over the world, causes massive economic losses (El-Tarabany and Ali, 2015). Generally, mastitis is an inflammatory reaction of the mammary gland that could be infectious (caused by pathogen infection) or non-infectious (caused by physical, chemical, or traumatic factors) (AbdEl Hamed and Kamel, 2020). Clinical mastitis (CM) is considered as one of the extremely poisonous disease problems in the dairy industry as it causes great economic loss and has a major impact on dairy cows' productivity and welfare (Nakov et al., 2014). There are series of pathogens that can induce mastitis in dairy cattle, these causative agents were allocated into two broad categories: one of them causes contagious mastitis such as Staphylococcus aureus, Streptococcus agalactiae, etc. that can be contagiously widespread from the infected udder mainly during milking. While the other category causes environmental mastitis such as Str. dysgalactiae, Str. Uber is, coliforms, etc. (Elbably and Asmaa, 2013). Mastitis can also be categorized into clinical and subclinical. CM is characterized by sudden occurrence, changes in milk content and appearance, a decline in milk production, and the appearance of the clinical signs of inflammation in the infected quarter. It is easily detected and diagnosed. While no visible clinical signs are observed either in the milk or on the udder of cows with sub-clinical mastitis, but the somatic cell count (SCC) increases, and the milk production reduces. This type is more serious and frequent (Khan and Khan, 2006). Costs due to mastitis are resulted from milk contamination due to antibiotic residues, diminished milk production, chronically infected cows culling, veterinary costs, and occasional mortalities. Moreover, mastitis has significant zoonotic importance through the shedding of pathogens and their toxins in the human consumed milk (Abebe et al., 2016).Mastitis occurrence in dairy herds occurs because of a complex interface between the agent, cow, and environment. Generally, the most popular risk factors for CM incidence in dairy herds are categorized into two groups: cow-level risk factors and environmental or managemental risk factors (Nakov et al., 2014). A large number of individual cow-level risk factors for $\mathrm{CM}$ incidence in dairy herds have been studied, including breed, parity, stage of lactation, the morphology of udder and teat, udder edema, age at first calving, milk production, milk leakage, milk somatic cell count and reproductive disorders by (Nyman et al., 2007) and (Peeler et al., 2000). The current study aimed to estimate the prevalence of $\mathrm{CM}$ and to study the individual cow-specific risk factors that affecting the prevalence of $\mathrm{CM}$ in Holstein Friesian (HF) dairy cattle in Egypt, such as age at $1^{\text {st }}$ calving, average daily milk yield (DMY), age,

Correspondence to: dina.abdallah@fvtm.bu.edu.eg 
number of parties, calving season, reproductive status, history of the previous mastitis and lactation stage.

\section{MATERIAL AND METHODS}

\subsection{Study area:}

A cross-sectional longitudinal survey was conducted to assess and evaluate the cow-level non-genetic risk factors for $\mathrm{CM}$ in Holstein dairy cows during the period from January 2018 to December 2019.

\subsection{Animals and management:}

Data used in this study were obtained from the records of a private dairy cattle farm located at $80^{\text {th }} \mathrm{Km}$ of CairoAlexandria desert road. About 1015 Holstein dairy cows' records were collected and analyzed. Cows on the farm are housed in a shaded open yard with free stalls, lined with a sand floor, and furnished in the summer with a cool spraying system thus reducing heat stress during the summer months. The farm applies the total mixed ration method with computerized calculating systems that control feeding portions according to the productivity and the reproductive status of animals. Water was supplied freely all day long. Pre-milking and post-milking udder hygiene measures were practiced through dipping the teats in iodine solution. The milking process was performed in a herringbone rapid exit milking parlor three times a day using machine milking, and milk parameters for each individual cow were recorded in a computerized database. Detection of CM depending on the presence of clinical signs on the udder such as hotness, redness, swelling, painful reaction, and hardness of udder tissues.

\subsection{Data variables and classification:}

The data variables are the outcome variable which is a dichotomous variable coded as $(0=$ Healthy, and $1=$ Mastitic), and the independent variables included the age at $1^{\text {st }}$ calving and the average daily milk yield (DMY) as continuous variables, and other categorical variables as the age classified into two categories: $\leq 5$ years old and $>5$ years old, Number of parties divided into primiparous, $2^{\text {nd }}$ parity, and multiparous ( $\geq 3$ parties), calving season classified into winter season which extends from 21 September to 20 March, and summer season that extend from 21 March to 20 September, reproductive status coded as $(0=$ Non-pregnant, and $1=$ Pregnant $)$, History of the previous mastitis coded as $(0=$ No, and $1=$ Yes $)$, and lactation stage classified into early-stage (1-90 days), midstage (91-180 days), and late-stage ( $>180$ days)

\subsection{Statistical analysis:}

All Statistical analysis practices were performed by the SPSS statistical software package (SPSS version 25). Firstly, the data were analyzed using the univariate logistic regression to determine the potential risk factors associated with $\mathrm{CM}$ incidence. All variables with $(P$-value $<0.05)$ in the initial univariate logistic regression analysis were examined for multicollinearity using tolerance and variance inflation factor (VIF). Multicollinearity is considered if tolerance $<0.04$ and VIF $>10$ (Miles, 2014). Then, the multivariate logistic regression using the enter method was conducted:

$$
\log \left[\frac{P}{1-P}\right]=\beta_{0}+\beta_{1} X_{1}+\cdots+\beta_{k} X_{k}
$$

Where, $\left[\frac{P}{1-P}\right]$ is the odds, $P$ is the probability of the outcome occurrence, $\beta_{0}$ is the Y-intercept, $\beta_{1}$ is the beta coefficient of the independent variable $\left(X_{1}\right)$ and $\beta_{k}$ is the beta coefficient ofthe independent variable $\left(X_{k}\right)$ (Boateng and Abaye, 2019). The results of the logistic regression were expressed as the (OR) of the associated predictor at a confidence interval of $95 \%$ and the p-value. Finally, the overall goodness of fit of the multivariate model was assessed using the receiver operating characteristics (ROC) curve.

\section{RESULTS}

The clinical mastitis (CM)prevalence concerning the age, parity, calving season, reproductive status, history of the previous mastitis, lactation stage, age at $1^{\text {st }}$ calving, and daily milk yield (DMY) were presented in (Table 1). Holstein Friesian (HF)cows aged > 5 years old showed a higher prevalence of $\mathrm{CM}(53.56 \%)$ than those of $\leq 5$ years old. The prevalence of $\mathrm{CM}$ varied according to the number of parties, $2^{\text {nd }}$ parity, and multiparous cows revealed a higher prevalence $(48.24 \%$ and $47.23 \%$, respectively) compared to the primiparous cow $(36.08 \%)$. Regarding the calving season, cows calved in summer showed a prevalence of $\mathrm{CM}$ greater than those that calved in winter (50.24\% and $38.36 \%$, respectively). Non-pregnant cows had a lower CM prevalence $(32.89 \%)$ than pregnant cows $(59.35 \%)$. According to the history of the previous mastitis, the CM prevalence was higher among cows with previous mastitis history $(51.66 \%)$ than cows that did not show CM previously (37.98\%). Also, lactating cows within the midstage $(52.69 \%)$ and early-stage $(44.59 \%)$ of lactation had higher $\mathrm{CM}$ prevalence than cows within the late lactation stage $(32.08 \%)$.

\begin{tabular}{llccc}
\multicolumn{6}{l}{ Table 1 Prevalence of Clinical mastitis in Holstein cows: } \\
\hline Factors & Class & $\begin{array}{c}\text { No. of } \\
\text { total } \\
\text { animals }\end{array}$ & $\begin{array}{c}\text { No. of } \\
\text { mastitic } \\
\text { animals }\end{array}$ & $\begin{array}{c}\text { Prevalence of } \\
\text { clinical mastitis } \\
(\%)\end{array}$ \\
\hline Age & $\leq 5$ years & 776 & 311 & $40.08 \%$ \\
Parity & $>5$ years & 239 & 128 & $53.56 \%$ \\
& Primiparous & 388 & 140 & $36.08 \%$ \\
& $2^{\text {nd }}$ parity & 284 & 137 & $48.24 \%$ \\
Calving Season & Multiparous & 343 & 162 & $47.23 \%$ \\
& Winter & 597 & 229 & $38.36 \%$ \\
Reproductive & Summer & 418 & 210 & $50.24 \%$ \\
status & Not pregnant & 614 & 202 & $32.89 \%$ \\
History of the & Pregnant & 401 & 238 & $59.35 \%$ \\
previous & No & 624 & 237 & $37.98 \%$ \\
mastitis & Yes & 391 & 202 & $51.66 \%$ \\
Lactation period & $1-90$ & 509 & 227 & $44.59 \%$ \\
(days) & $91-180$ & 241 & 127 & $52.69 \%$ \\
& $>180$ & 265 & 85 & $32.08 \%$ \\
\hline
\end{tabular}

As described in table (2), the mean age at $1^{\text {st }}$ calving of the mastitic cows was 1.98 years while the mean age at $1^{\text {st }}$ calving of the healthy cows was 2.01 years. Also, mastitic cows had relatively lower DMY compared with their healthy contemporaries (31.9 and $32.3 \mathrm{~kg}$, respectively).

Table 2 Descriptive statistics of the continuous independent variables expressed as the mean and standard error:

\begin{tabular}{lcc}
\hline & Age at $~^{\text {st }}$ calving & DMY \\
\cline { 2 - 3 } Clinical Mastitis & Mean \pm S.E. & Mean \pm S.E. \\
\cline { 2 - 3 } Healthy & $1.98 \pm 0.007$ & $31.9 \pm 0.65$ \\
& $2.01 \pm 0.008$ & $32.3 \pm 0.57$ \\
\hline
\end{tabular}

Table (3) showed the results of the univariate logistic analysis. The univariate logistic regression models showed that the age at $1^{\text {st }}$ calving, parity, calving season, reproductive status, history of the previous mastitis, and lactation stage were all significantly associated with the occurrence of CM. All the initial risk factors were checked for the absence of multicollinearity and none of them showed a high correlation with each other. So, except for DMY which was not significant in the univariate analysis, 
all the other significant variables were introduced in the multivariate analysis.

Table 3 The potential risk factors affecting the prevalence of the clinical mastitis in Holstein cows using Univariate logistic regression model

\begin{tabular}{|c|c|c|c|c|}
\hline Factors & Class & OR & $95 \% \mathrm{CI}$ & P-value \\
\hline Age at $1^{\text {st }}$ calving & & 2.4 & $1.2-4.8$ & $0.013 *$ \\
\hline Daily milk yield & & 0.99 & $0.99-1.007$ & $0.64^{\mathrm{NS}}$ \\
\hline Age & $\begin{array}{l}\leq 5 \text { years } \\
>5 \text { years }\end{array}$ & $\begin{array}{c}\text { Reference } \\
1.72\end{array}$ & $1.29-2.31$ & $0.000^{* * * *}$ \\
\hline Parity & Primiparous & Reference & - & \\
\hline & $\begin{array}{l}2^{\text {nd }} \text { parity } \\
\text { Multiparous }\end{array}$ & $\begin{array}{l}1.65 \\
1.59\end{array}$ & $\begin{array}{l}1.21-2.26 \\
1.18-2.13\end{array}$ & $0.002^{* *}$ \\
\hline Calving season & $\begin{array}{l}\text { Winter } \\
\text { Summer }\end{array}$ & $\begin{array}{c}\text { Reference } \\
1.62\end{array}$ & $1.26-2.09$ & $0.000^{* * * *}$ \\
\hline Reproductive status & $\begin{array}{l}\text { Not pregnant } \\
\text { Pregnant }\end{array}$ & $\begin{array}{c}\text { Reference } \\
3\end{array}$ & $\begin{array}{c}- \\
2.3-3.9\end{array}$ & $0.000^{* * * *}$ \\
\hline $\begin{array}{l}\text { History of the previous } \\
\text { mastitis }\end{array}$ & $\begin{array}{l}\text { No } \\
\text { Yes }\end{array}$ & $\begin{array}{c}\text { Reference } \\
1.75\end{array}$ & $1.35-2.25$ & $0.000^{* * * *}$ \\
\hline Lactation period (days) & $\begin{array}{l}1-90 \\
91-180 \\
>180\end{array}$ & $\begin{array}{c}\text { Reference } \\
1.38 \\
0.59\end{array}$ & $\begin{array}{c}- \\
1.02-1.88 \\
0.43-0.8\end{array}$ & $0.000^{* * * *}$ \\
\hline
\end{tabular}

$\mathrm{OR}=$ odds ratio, $\mathrm{CI}=$ confidence interval, $*=$ significant at $p$-value $<0.05, * *=$ significant at $p$-value $<0.001, * * *=$ significant at $p$-value $<0.0001$ and $\mathrm{NS}=$ nonsignificant.

The following step was conducting the multivariate logistic regression analysis with the enter method. The age at $1^{\text {st }}$ calving showed a significant direct relationship with the prevalence of $\mathrm{CM}$ in Holstein dairy cows $(\beta=1.19$ at $P$ value $=0.003)$. Regarding the age category of the lactating cow, cows aged $>5$ years had a higher odds of CM 1.79 times higher than cows of $\leq 5$ years old $(\mathrm{OR}=1.79,95 \%$ $\mathrm{CI}=1.12-2.84$ ). The odds of $\mathrm{CM}$ for cows calved in summer were estimated to be greater than the reference group (winter calving season) by 1.84 times $(\mathrm{OR}=1.84$, 95\% $\mathrm{CI}=1.36-2.49$ ). It was also revealed that the odds of $\mathrm{CM}$ were 7.27 times greater for the pregnant cows as opposed to the non-pregnant cows $(\mathrm{OR}=7.27,95 \% \mathrm{CI}=5-10.6)$. In accordance with the history of the previous mastitis, the previously infected cow with $\mathrm{CM}$ had a higher odds of 1.81 times than those with no history of the previous mastitis $(\mathrm{OR}=1.81,95 \% \mathrm{CI}=1.22-2.69)$. Dairy cows within the mid-stage and the late-stage of lactation showed lower odds of $\mathrm{CM}$ by ( 0.59 and 0.18 times, respectively) than cows within the early stage of lactation $(\mathrm{OR}=0.59,95 \% \mathrm{CI}=0.39$ -0.88 and $\mathrm{OR}=0.18,95 \% \mathrm{CI}=0.12-0.29$, respectively) (Table 4).

Finally, the overall goodness of fit of the final multivariate regression model was proved in the ROC curve (Figure 1). The area under the curve (AUC) was 0.75 at a $95 \%$ confidence interval $(0.72-0.78)$ which significantly differed from 0.05 at $P$-value $=0.001$, indicating the very good predictive ability of the final multivariate logistic regression model.

\section{DISCUSSION}

Mastitis is a complex disease of multifactorial etiology that causes massive economic losses in the dairy industry worldwide. Whereas the control of mastitis in dairy herds depends on the identification and elimination of risk factors associated with the environment, management, and the cows, we tried to study the effect of different non-genetic factors on the occurrence of the $\mathrm{CM}$ in the Holstein Friesian dairy cow such as the age at $1^{\text {st }}$ calving, DMY, age, parity, calving season, reproductive status, history of the previous mastitis, and lactation stage.

Table 4 The odds ratio for different factors affecting the prevalence of $\mathrm{CM}$ in the Holstein cows using multivariate logistic regression model

\begin{tabular}{llllllll}
\multicolumn{6}{l}{ in the Holstein cows using multivariate logistic regression model } & \\
\hline Factor & Categories & $\beta$ & S.E. & $\begin{array}{l}\text { Wal } \\
\text { d }\end{array}$ & OR & $\begin{array}{l}95 \% \\
\text { CI }\end{array}$ & p-value \\
\hline $\begin{array}{l}\text { Age at } 1^{\text {st }} \\
\text { calving }\end{array}$ & 1.19 & 0.39 & 9.09 & 3.3 & 1.52 & $0.003^{* *}$ \\
& & & & & & - &
\end{tabular}

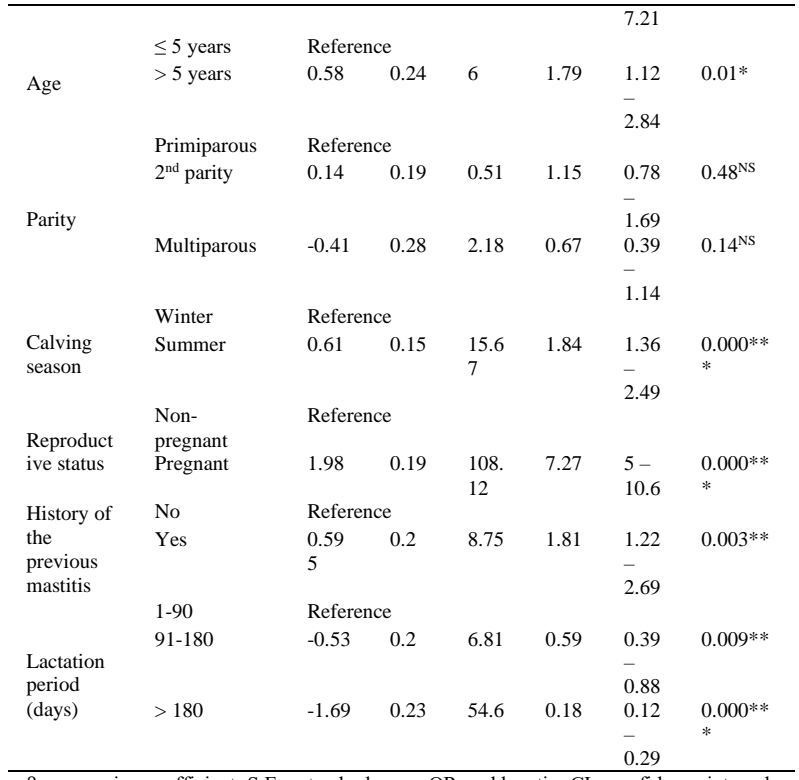

$\beta=$ regression coefficient, $\mathrm{S}$.E. $=$ standard error, $\mathrm{OR}=$ odds ratio, $\mathrm{CI}=$ confidence interval, $p$-value $<0.0001$ and $\mathrm{NS}=$ non-significant.

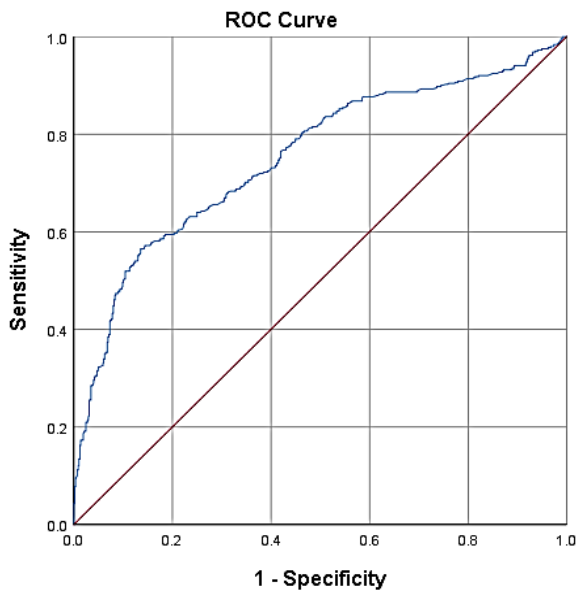

Fig 1 ROC curve: A tool for measuring the multivariate logistic regression model goodness of fit.

Our finding showed that age at $1^{\text {st }}$ calving, age, parity, calving season, reproductive status, history of the previous mastitis, and lactation stage were potential risk factors for the occurrence of $\mathrm{CM}$ in HF. Regarding the age at $1^{\text {st }}$ calving, it was demonstrated that increasing the age of the cow at the $1^{\text {st }}$ calving was directly associated with increasing the prevalence of the CM. This might be due to the full development of the udder with increasing the age at the first calving and increasing the milk yield in the first lactation (Eastham et al., 2018). This result agreed with Oltenacu and Ekesbo (1994) who reported that age at the first calving was a significant risk factor for mastitis. Also, this result came in agreement with Nitz et al. (2020) who proved that cows calving at older ages were more susceptible to mastitis $17 \pm 3$ days postpartum with coryneform and non-aureus staphylococci (NAS) than those calving in younger ages. Older cows $>5$ years were more likely to be infected with mastitis 1.72 times than younger ones. This might be due to older cows had a large pendulous udder exposed to the udder and teat injuries which result in a high probability of infection and mastitis (Awale et al., 2012). Also, it may be attributed to the dilated and permanent partially opened teat canal in the older cows with frequent lactations which are a strong 
factor for the introduction of the infection from the surrounding skin or the external environment (Shittu et al., 2012). Such results were in agreement with Shittu et al. (2012) and Abebe et al. (2016). Concerning the calving season, it was revealed that $\mathrm{CM}$ was more likely in cows calved during the summer season than the winter season. Consistent with our findings, Boujenane et al. (2015) reported that the increased cases of mastitis during summer might be due to the proliferation of pathogens during the hot weather in the surrounding environment, especially around the water troughs. On the contrary, Kerro Dego and Tareke (2003) revealed that bovine mastitis was frequent in cows calved in the wet season than in the dry season.

The current study revealed that pregnant dairy cow has a probability to $\mathrm{CM}$ infection 7.27 times higher than nonpregnant ones. This might be due to the stress of the pregnancy, in addition to the milk production causing immune suppression and pregnant cow become sensitive to the infection like mastitis. Dairy cows with a history of the previous mastitis had a higher risk of CM than those that did not expose previously that might be associated with persistent bacteria in the mammary gland and reinfection after treatment. These results were in agreement with Tezera and Aman Ali (2021), who found that cows that suffered from CM previously $(66.3 \%)$, were more susceptible to mastitis than non-exposed cows (31.6\%). Finally, regarding the lactation stage, it was revealed that the prevalence of CM was higher during the early stage of lactation than in the mid and late stages. This might be attributed to the marked sensitivity of the udder to infectious agents and the higher physiological demands after calving (Boujenane et al., 2015). Also, it might be due to the delay of the neutrophils diapedesis into the mammary gland in recently calved cows (Hagnestam et al., 2007). On the other hand, the reduced antioxidant defense mechanisms and increased oxidative stress due to lipid peroxidase due to the high demand in the early stage of lactation are predisposing factors to mastitis and other productive diseases (Sharma et al., 2011). These results came in agreement with Koeck et al. (2012), who found that the majority of $\mathrm{CM}$ cases were in the first lactation stage by a ratio of $32.7 \%$ at the $1^{\text {st }}$ month, $9.4 \%$ at $2^{\text {nd }}$ month, and $8.6 \%$ at $3^{\text {rd }}$ month of lactation. Also, Chegini et al. (2016) attributed the cause to the high tension of peak milk production at the early lactation stage.

\section{CONCLUSION}

In conclusion, $\mathrm{CM}$ is a widely spread multifactorial complex disease in dairy farms. The majority of the cowlevel non-genetic risk factors such as age at the first calving, age, calving season, reproductive status, history of the previous mastitis, and lactation stage were shown to affect the prevalence of $\mathrm{CM}$, hence the control and the elimination of these factors will help a lot in reducing the $\mathrm{CM}$ rates. Older multiparous cows and during the early stage of lactation and pregnant cows are more susceptible to udder infections, and hence they should be supplied with a balanced ration with all essential supplements to face the high demands of pregnancy and lactation without affecting the immune response. Also, during the summer season, efficient cooling systems should be used to reduce the heat stress in the hot weather but with caution to avoid the dampness of the bedding and the proliferation of pathogens in the surrounding environment.

\section{CONFLICT OF INTEREST}

The authors declare that they have no conflicts of interest for current data

\section{AUTHORS' CONTRIBUTION}

All authors contributed equally.

\section{REFERENCES}

1. Abd-El Hamed, A., Kamel, E., 2020. Incidence and Economics of Clinical Mastitis of Holstein Friesian Dairy Cows under Egyptian Condition. Benha Veterinary Medical Journal 39: 119-124.

2. Abebe, R., Hatiya, H., Abera, M., Megersa, B., Asmare, K., 2016. Bovine mastitis: Prevalence, risk factors and isolation of Staphylococcus aureus in dairy herds at Hawassa milk shed, South Ethiopia. BMC Veterinary Research 12: 1-11.

3. Awale, M.M., Dudhatra, G.B., Avinash, K., Chauhan, B.N., Kamani, D.R., Modi, C.M., Patel, H.B., Mody, S.K., 2012. Bovine mastitis: a threat to economy. Open Access Scientific Reports 1(5): 295 (doi:10.4172/scientificreports.295).

4. Boateng, E.Y., Abaye, D.A., 2019. A Review of the Logistic Regression Model with Emphasis on Medical Research. Journal of Data Analysis and Information Processing 07: 190 207.

5. Boujenane, I., El Aimani, J., By, K., 2015. Incidence and occurrence time of clinical mastitis in Holstein cows. Turkish Journal of Veterinary Animal Sciences 39: 42-49.

6. Chegini, A., Hossein-Zadeh, N.G., Hosseini-Moghadam, H., Shadparvar, A.A., 2016. Relações genéticas e ambientais entre produção de leite e tipos diferentes de mastite e hiperqueratose em vacas holandesas. Acta Scientarium Animal Sciences. 38 191-196.

7. Eastham, N.T., Coates, A., Cripps, P., Richardson, H., Smith, R., Oikonomou, G., 2018. Associations between age at first calving and subsequent lactation performance in UK Holstein and Holstein-Friesian dairy cows. PLoS ONE 16(1): e0244825 (13 pages).

8. El-Tarabany, M.S., Ali, M.A., 2015. Incidence, production and economic losses of clinical mastitis in Egyptian Holstein cows. IranianJournal of Applied Animal Science 5: 813-818.

9. Elbably, M., Asmaa, H., 2013. Risk Factors Associated with Mastitis Occurrence in Dairy Herds in Benisuef, Egypt. World`s Veterinary Journal 6: 5-10

10. Hagnestam, C., Emanuelson, U., Berglund, B., 2007. Yield losses associated with clinical mastitis occurring in different weeks of lactation. Journal of Dairy Sciences 90: 2260-2270.

11. Kerro Dego, O., Tareke, F., 2003. Bovine mastitis in selected areas of southern Ethiopia. Tropical Animal Health and Production. 35: 197-205.

12. Khan, M.Z., Khan, A., 2006. Basic facts of mastitis in dairy animals: a review. Pakistan Veterinary Journal. 26: 204-208.

13. Koeck, A., Miglior, F., Kelton, D.F., Schenkel, F.S., 2012. Alternative somatic cell count traits to improve mastitis resistance in Canadian Holsteins. Journal of Dairy Sciences. 95: 432-439.

14. Miles, J., 2014. Tolerance and variance inflation factor. Wiley StatsRef. Statistics Reference Online.

15. Nakov, D., Hristov, S., Andonov, S., Trajchev, M., 2014. Udder-related risk factors for clinical mastitis in dairy cows. Veterinary Arhiv Journal. 84: 111-127.

16. Nitz, J., Krömker, V., Klocke, D., Wente, N., Zhang, Y., Seeth, M.T., 2020. Intramammary infections in heifers-time of onset and associated risk factors. Animals 10: 1-17.

17. Nyman, A.-K., Ekman, T., Emanuelson, U., Gustafsson, A.H. Holtenius, K., Waller, K.P., Sandgren, C.H., 2007. Risk factors associated with the incidence of veterinary-treated clinical mastitis in Swedish dairy herds with a high milk yield and a low prevalence of subclinical mastitis. Preventive Veterinary Medicine. 78: 142-160.

18. Oltenacu, P.A., Ekesbo, I., 1994. Epidemiological study of clinical mastitis in dairy cattle. Veterinary Research. 25: 208 212.

19. Peeler, E.J., Green, M.J., Fitzpatrick, J.L., Morgan, K.L., Green, L.E., 2000. Risk factors associated with clinical 
mastitis in low somatic cell count British dairy herds. Journal of Dairy Sciences. 83: 2464-2472.

20. Sharma, N., Singh, N.K., Singh, O.P., Pandey, V., Verma, P.K., 2011. Oxidative Stress and Antioxidant Status during Transition Period in Dairy Cows. Asian Australasian Journal of Animal Sciences. 24: 479-484.

21. Shittu, A., Abdullahi, J., Jibril, A., Mohammed, A.A., Fasina,
F.O., 2012. Sub-clinical mastitis and associated risk factors on lactating cows in the Savannah Region of Nigeria. BMC Veterinary Research. 8: 1-8.

22. Tezera, M., Aman Ali, E., 2021. Prevalence and associated risk factors of Bovine mastitis in dairy cows in and around Assosa town, Benishangul-Gumuz Regional State, Western Ethiopia. Veterinary Medicine and Science. 7(4): 1280-1286. 